\title{
WYKLUCZENIE SPOŁECZNE OSÓB NIEPEŁNOSPRAWNYCH. RYS PROBLEMATYKI Z PERSPEKTYWY PASTORALISTY
}

Social exclusion of people with disabilities. An outline of the issues from the perspective of pastoralisty

Wykluczenie społeczne jest w ostatnich latach bardzo modnym pojęciem. Media i opracowania naukowe poświęcają wiele miejsca na opisywanie tego zjawiska. Obecnie na gruncie nauk społecznych (m.in. w psychologii, socjologii) zjawisko wykluczenia badane jest pod wieloma różnymi aspektami, a naukowcy próbują wciąż doszukiwać się przyczyn, przebiegu i skutków marginalizacji różnych grup społeczeństwa.

Określenie „wykluczenie społeczne” pierwotnie zostało użyte przez francuskiego ministra dobrobytu społecznego René Lenoira (1974) w stosunku do ludzi uznanych za nieprzystosowane do życia w społeczeństwie industrialnym, żyjących na marginesie społeczeństwa oraz osób, które nie są objęte żadnym systemem ubezpieczeń. Termin „wykluczenie społeczne” po raz pierwszy wystąpiło w oficjalnym dokumencie Komisji Europejskiej dotyczącym programu walki z ubóstwem w roku 1990. ${ }^{1}$

Trudno mówić o spójnym syndromie wykluczenia, a związki pomiędzy poszczególnymi kryteriami wykluczenia takimi jak bezrobocie, ubóstwo czy dyskryminacja są dosyć słabe. Spośród jedenastu barier pełnego uczestnictwa w życiu społecznym: podeszły wiek (50+),

1 J. Nogowski, Wykluczenie społeczne w kontekście ubóstwa i bezdomności, Civitas et lex 2015/1(5), s. 55. 
samotność, ubóstwo, mieszkanie na wsi, niskie wykształcenie własne i ojca, uzależnienie od alkoholu lub narkotyków, konflikt z prawem, poczucie dyskryminacji, niepełnosprawność, bezrobocie można wyróżnić cztery grupy czynników:

1. Wykluczenie strukturalne - miejsce zamieszkania (wieś), niskie wykształcenie własne i ojca i skorelowany z nimi niski dochód

2. Wykluczenie fizyczne - podeszły wiek, niepełnosprawność i w mniejszym stopniu niskie wykształcenie ojca

3. Wykluczenie normatywne - uzależnienie od alkoholu lub narkotyków, konflikt z prawem, samotność i bycie ofiarą dyskryminacji

4. Wykluczenie materialne - ubóstwo i bezrobocie. ${ }^{2}$

Pojęcie wykluczenia społecznego wiąże się na poziomie językowym z wieloma innymi o podobnym znaczeniu. Przed jego upowszechnieniem, co nastąpiło na początku XXI wieku, w polskim piśmiennictwie naukowym i pozanaukowym częściej używano określeń pochodzących od słowa „margines”, np. marginalizacja, marginalność, marginesowość, marginalny. ${ }^{3}$

Przez marginalizację społeczną można rozumieć stan wykorzenienia, nieuczestniczenia jednostek lub grup w instytucjonalnym porządku społecznym oraz procesy, które do owego stanu prowadzą. Takie rozumienie marginalizacji uwzględnia zarówno właściwości porządku społecznego, określające normatywne ramy, formy i warunki uczestnictwa w nim, jak i różnorodne czynniki: aksjologiczne, historyczne, ekonomiczne, polityczne, społeczne, prawne czy osobowościowe, wpływające na różnicowanie zakresu i form tego uczestnictwa. Marginalizacja rozumiana jako ograniczenie uczestnictwa bądź wyłączenie z oficjalnego czy instytucjonalnego porządku społecznego nie oznacza oczywiście fizycznego przemieszczania ludzi poza „ramy społeczeństwa”. Fakt, że „ludzie marginesu” pozostają

2 D. Kubicki, Ubóstwo i wykluczenie społeczne osób starszych, Ekspertyza przygotowana w ramach projektu „EAPN Polska - razem na rzecz Europy Socjalnej”, http://www.eapn.org.pl/ (03.12.2016), s. 8.

3 Por. R. Szarfenberg, Pojęcie wykluczenia społecznego, w: http://rszarf.ips.uw.edu. pl/pdf/pojecie_ws.pdf (11.12.2016), s. 1 . 
w społeczeństwie, oznacza, że „margines społeczny” może stać się - i często bywa - dodatkowym czynnikiem marginalizacji społecznej, obok immanentnych źródeł tego zjawiska, tkwiących w sektorze partycypacji społecznej. ${ }^{4}$

Marginalizację niekiedy określa się opierając się na różnych aspektach atrybutów konkretnego człowieka w zakresie m.in. wiedzy, umiejętności, zdrowia, sprawności, mobilności, kontaktów, motywacji. W tym kontekście można wyodrębnić marginalizację niezawinioną (np. niepełnosprawni) oraz marginalizację z wyboru (np. żebracy). W wielu podejściach zwraca się uwagę na podatność zmarginalizowanych i wykluczonych na skutki negatywnych wydarzeń, które dla grup dominujących nie są żadnym zagrożeniem. Inaczej mówiąc, odporność różnych grup na pogorszenie sytuacji w wyniku wystąpienia tego, co nazywane jest ryzykami socjalnymi (m.in. choroba, macierzyństwo, niepełnosprawność, starość) jest różna. Zmarginalizowani mają ją zdecydowanie niższą w porównaniu z osobami z grup dominujących. ${ }^{5}$

Człowiek jest istotą społeczną. Wykluczenie społeczne jest przede wszystkim większym lub mniejszym zanegowaniem tej rzeczywistości. Jest też w różnym stopniu destrukcją społecznej natury człowieka i jego relacji do społeczności. Wiemy też, że wykluczenie społeczne jest zakwestionowaniem potrzeby rozwoju człowieka w społeczności ludzkiej. Człowiek bowiem ma niezbywalne prawo do takiego integralnego rozwoju w wybranej przez siebie społeczności. Co więcejgodność osoby ludzkiej wymaga ogólnoludzkiej solidarności i miłości preferencyjnej ubogich. ${ }^{6}$

4 Por. J. Kwaśniewski, Postrzeganie marginalizacji oraz strategii środków kontroli społecznej, w: J. Kwaśniewski (red.), Kontrola społeczna procesów marginalizacji, Warszawa 1997, s. 7-8.

5 Por. R. Marks-Bielska, Marginalizacja społeczno-ekonomiczna w'sietle polskiej literatury przedmiotu - lata 90., Polityka Społeczna” nr 3 (2003), s. 9-11.

6 Por. Jan Paweł II, enc. Sollicitudo rei socialis, nr 47 . 
W większości definicji wykluczenie społeczne jest określane w kategoriach niemożności uczestniczenia $\mathrm{w}$ istotnych aspektach życia społecznego, gospodarczego, politycznego i kulturalnego danego społeczeństwa. Ponadto nieuczestniczenie to nie jest wynikiem wyboru jednostki lecz przeszkód, jakie ona napotyka. ${ }^{7}$

Osoby niepełnosprawne muszą w swoim życiu pokonać wiele przeszkód nie tylko są to przeszkody architektoniczne, ale przeszkody wynikających z ograniczeń samych niepełnosprawnych oraz z ograniczeń osób pomiędzy którymi żyją. Duża grupa osób niepełnospranych doświadcza z tych różnorakich przyczyn wykluczenia społecznego.

Współcześnie w życiu większości ludzi można wyróżnić trzy podstawowe obszary aktywności: zawodową, społeczną i rodzinną. W zależności od jednostkowych losów życiowych osoba niepełnosprawna może być wykluczana na każdym z tych obszarów, bądź spędzać szczęśliwie życie w pełni zintegrowana ze społeczeństwem. ${ }^{8}$

Pojęcie niepełnosprawność zwykło się rozpatrywać w trzech zasadniczych kategoriach: „uszkodzenia” (impairment), czyli dysfunkcji fizjologicznych, anatomicznych i psychicznych, „niepełnosprawności funkcjonalnej" (disability), czyli obniżonej sprawności wykonywania czynności oraz „upośledzenia” (handicap) odnoszącego się do środowiskowych zaburzeń funkcjonowania. Powyższymi kategoriami posługuje się przyjęta w 1980 r. przez Światową Organizację Zdrowia Międzynarodowa Klasyfikacja Uszkodzeń, Niepełnosprawności i Upośledzeń. ${ }^{9}$

Powyższa Międzynarodowa Klasyfikacja Uszkodzeń, Niepełnosprawności i Upośledzeń spotkała się z krytyką za zbyt silne akcentowanie aspektów medycznych niepełnosprawności i niewystarczające podkreślanie znaczenia utrudnień środowiskowych, odnoszących się do otoczenia fizycznego (np. bariery architektoniczne) i społecznego

${ }^{7}$ Por. J. Nogowski, Wykluczenie społeczne w kontekście ubóstwa i bezdomności, dz. cyt., s. 56.

8 Por. D. Kubicki, Ubóstwo i wykluczenie społeczne osób starszych, dz. cyt., s. 10.

9 Por. M. Kilian, Niepełnosprawni w społeczeństwie, Polityka Społeczna, 404 -405(11 -12), 2007, s. 14. 
(np.: uprzedzenia i stereotypy, zachowania dyskryminacyjne, bariery kulturowe) w etiologii niepełnosprawności. Klasyfikacja ta przyjmuje, iż uszkodzenie jest źródłem niepełnosprawności i upośledzenia, a osoba niepełnosprawna na drodze leczenia i rehabilitacji ma dostosować się do warunków otoczenia. A przecież upośledzenie, będące wyrazem zależności człowieka od jego środowiska, można znosić tak poprzez zmianę człowieka, jak tegoż środowiska - społecznego czy fizycznego. ${ }^{10}$

W odpowiedzi na postawione zarzuty WHO przedstawiła w $2001 \mathrm{r}$. ostateczną wersję Międzynarodowej Klasyfikacji Funkcjonowania, Niepełnosprawności i Zdrowia - ICF (WHO 2001), stanowiącą zmodyfikowaną i skorygowaną wersję klasyfikacji pochodzącej z $1980 \mathrm{r}$. W klasyfikacji tej termin niepełnosprawność (disability) zastąpiło „ograniczenie aktywności” (activity limitations), a „upośledzenie” (handicap) - „ograniczenie uczestnictwa” (participation restriction). Nowa, biopsychospołeczna koncepcja niepełnosprawności łączy aspekty biologiczne i społeczne niepełnosprawności. Przyjmuje, iż niepełnosprawność jest wynikiem złożonych relacji między właściwościami osoby (stan zdrowia i czynniki osobiste) a właściwościami środowiska społecznego i fizycznego, stanowiących możliwe źródło trudności odczuwanych przez osoby niepełnosprawne. Podkreślono, że bezpośrednią przyczyną zaburzenia funkcjonowania może być środowisko społeczne, nawet w sytuacji braku uszkodzenia, co znajduje wyraz w przypadku np. społecznej stygmatyzacji osoby wyleczonej z choroby psychicznej lub dyskryminacji zawodowej osób z predyspozycjami genetycznymi w kierunku jakiejś choroby. ${ }^{11}$

Wykluczenie z życia społecznego osoby niepełnosprawnej najbardziej jest widoczne w trzech obszarach: $\mathrm{z}$ systemu edukacji, dostępu do pracy oraz kultury. ${ }^{12}$

\footnotetext{
10 Tamże.

11 Tamże.

12 Zob. Janocha W., Marginalizacja i wykluczenie osób niepełnosprawnych zobszarów życia społecznego i religijnego, Roczniki Nauk o Rodzinie i pracy Socjalnej, 4(59) 2012, s. 377.
} 
Edukację osób niepełnosprawnych możemy określić jako system przedsięwzięć dydaktyczno-wychowawczych, uwzględniający potrzeby $\mathrm{i}$ indywidualne możliwości edukacyjne tych osób. W ten sposób niepełnosprawni zdobywają zdolności, umiejętności i postawy pozwalające na funkcjonowanie w życiu rodzinnym, społecznym i zawodowym. Pomimo zmian w prawie oświatowym nadal wiele dzieci uczy się w systemie segregacyjnym (szkoły specjalne i oddziały specjalne w szkołach masowych) jest objętych indywidualnym nauczaniem, a nawet ma odroczony na jakiś czas obowiązek szkolny. System szkół specjalnych wytworzył głęboki podział pomiędzy dziećmi i młodzieżą niepełnosprawną a ich pełnosprawnymi rówieśnikami. Krytycy tego systemu twierdzą, że szkoły specjalne ograniczają możliwości zawierania przyjaźni przez dzieci niepełnosprawne z ich pełnosprawnymi rówieśnikami, jak również niepełnosprawni mają tam ograniczony program zajęć i niższe wymagania. Spogladając na statystyki można wysnuć wniosek, że osoby niepełnosprawne są wciąż gorzej wykształcone niż osoby sprawne, co przekłada się w ich dostępie do pracy zarobkowej. Prawie 49,9\% tej zbiorowości legitymuje się co najwyżej wykształceniem podstawowym. Powoduje to trudności w zdobyciu i utrzymaniu zatrudnienia. Praca nie tylko stanowi źródło dochodu, ale stwarza warunki do samorealizacji. Dla wielu stanowi cel i sens życia. Bez pracy osoba niepełnosprawna skazana jest na ekonomiczne uzależnienie od innych osób (8\%) lub na korzystanie ze świadczeń społecznych (86\%) (zasiłek, renta socjalna, emerytura itp.). Niestety i w tym obszarze udział osób niepełnosprawnych jest marginalny tylko $8 \%$ tej populacji utrzymuje się z pracy. ${ }^{13}$ To rzutuje na ich sytuację materialną, a przez to ogranicza ich aktywność społeczną oraz wyklucza z głównego nurtu życia społecznego. ${ }^{14}$

Ograniczenie osób niepełnosprawnych gdy chodzi o dostęp do kultury można rozpatrywać w dwóch aspektach: osoba niepełnosprawna jako odbiorca i jako twórca kultury. Udział w wydarzeniach kulturalnych przez osoby niepełnosprawne związany jest z wieloma

13 Por. www.mpips.gov.pl/userfiles/File/mps/NSIS.pdf, s. 29 (07.04.2015).

14 Zob. C. Barnes, G. Mercer, Niepetnosprawność, Warszawa 2008, s. 56-63. 
czynnikami takimi jak: cechy demograficzno-społeczne (np. dostęp do oświaty, wsparcie socjalne, bariery architektoniczne), bariery indywidualne (płeć, wiek, wykształcenie, warunki materialne) oraz stopień niepełnosprawności.

Maja na uwadze te czynniki, a w szczególności stopień niepełnosprawności (trudności z pokonywaniem barier architektonicznych np. schodów) możemy powiedzieć, że udział osób niepełnosprawnych w wydarzeniach kulturalnych jest zdecydowanie niższy niż osób w pełni sprawnych. Również twórcy niepełnosprawni napotykają na większe trudności niż pełnosprawni. Dotyczy to zarówno warsztatu pracy, gdzie zachodzi potrzeba dostosowania go do potrzeb i sprawności osoby jak i również braku kompetentnej osoby, pod opieką której osoba niepełnosprawna może uczyć się podstaw uprawiania sztuki i rozwijania talentów. ${ }^{15}$

Papież Jan Paweł II w przesłaniu do uczestników międzynarodowego sympozjum na temat: „Godność i prawa osoby z upośledzeniem umysłowym“ podkreślał, że: „Z uznaniem praw musi zatem łączyć się szczere dążenie wszystkich do stworzenia konkretnych warunków życia, struktur pomocy i ochrony prawnej odpowiadających potrzebom i dynamice rozwoju osoby niepełnosprawnej oraz tych, którzy jej towarzyszą, przede wszystkim członków rodziny. Niezależnie od wszelkich innych względów lub interesów indywidualnych czy grupowych należy troszczyć się o integralne dobro tych osób, nie można im też odmawiać niezbędnej pomocy i ochrony, nawet jeśli pociąga to za sobą zwiększone koszty ekonomiczne i społeczne. ${ }^{16}$

Według Jana Pawła II „społeczeństwo, w którym byłoby miejsce tylko dla osób w pełni sprawnych, całkowicie samodzielnych i niezależnych, nie byłoby społeczeństwem godnym człowieka.

\footnotetext{
15 Zob. J. Kirenko, Twórczość osób niepełnosprawnych, w: W. Janocha (red.), Niepełnosprawność. Wybrane aspekty sytuacji osób niepełnosprawnych i ich rodzin, red. W. Janocha, Kielce 2006, s. 95-96.

16 Jan Paweł II, Przesłanie Jana Pawła II do uczestników międzynarodowego sympozjum na temat: Godność i prawa osoby z upośledzeniem umysłowym, nr 4, http://www.opoka.org.pl/biblioteka/W/WP/jan_pawel_ii/przemowienia/uposledzenie_05012004.html (3.12.2016).
} 
Dyskryminacja według kryterium sprawności jest nie mniej haniebna niż dyskryminacja z powodu rasy, płci czy religii. Ukryta forma dyskryminacji występuje też w polityce i programach edukacyjnych, które próbują przemilczeć lub zanegować ograniczenia osoby niepełnosprawnej, proponując style życia i cele nie odpowiadające jej możliwościom, a więc frustrujące i niewłaściwe. Sprawiedliwość nakazuje bowiem uważnie i z miłością przyglądać się życiu drugiego człowieka i zaspokajać poszczególne, odmienne potrzeby każdego, biorąc pod uwagę jego zdolności i ograniczenia. ${ }^{\text {"17 }}$

Papież Franciszek 12 czerwca 2016 roku w przemówieniu do uczesników Jubileuszu chorych i niepełnosprawnych wskazał że „...dziś uważa się, że osoba chora lub niepełnosprawna nie może być szczęśliwa, ponieważ nie jest w stanie zrealizować stylu życia narzuconego przez kulturę przyjemności i rozrywki. W czasach, gdy pewna troska o ciało stała się masowym mitem, a zatem interesem ekonomicznym, to co jest niedoskonałe musi być przysłonięte, ponieważ wymierzone jest w szczęście i spokój ludzi uprzywilejowanych i ponieważ podważa model dominujący. Lepiej trzymać te osoby w separacji, w jakimś ogrodzeniu - może i złotym - czy też w „rezerwatach” litości czy pomocy społecznej, aby nie opóźniały rytmu fałszywego dobrobytu. W niektórych przypadkach, uważa się wręcz, że lepiej jest pozbyć się ich jak najszybciej, ponieważ stają się one nieznośnym obciążeniem finansowym w czasach kryzysu”.

Papież zdecydowanie odrzucił taki stosunek do osób niepełnosprawnych, podkreślając jak ważną rolę pełnią one w życiu społeczeństwa. „Ale w istocie jakąż iluzją żyje dzisiejszy człowiek, kiedy zamyka oczy w obliczu choroby i niepełnosprawności! Nie rozumie on prawdziwego sensu życia, które pociąga za sobą także akceptację cierpienia i ograniczeń. Świat nie staje się lepszy, ponieważ składa się wyłącznie z osób pozornie „doskonałych”, by nie powiedzieć „fałszywych”, ale kiedy wzrasta solidarność między ludźmi, wzajemna

17 Tamże, nr 3. 
akceptacja i szacunek. Jakże prawdziwe są słowa Apostoła: „Bóg wybrał właśnie to, co niemocne, aby mocnych poniżyć” (1 Kor 1,27)!”18

Pisząc o przejawach wykluczania osób niepełnosprawnych z życia społecznego trzeba wspomnieć (na szczęście coraz rzadszym zjawisku) wykluczenie niepełnospranych z przestrzeni parafii i wspólnot modlitewnych. Pierwszą istotną kwestią to bariery architektoniczne w świątyniach, które utrudniają, a czasami uniemożliwiają obecność w kościele (np. brak odpowiednich podjazdów i wejść dla osób poruszających się na wózkach inwalidzkich, brak stosownych konfesjonałów dla osób słabosłyszących itp.). ${ }^{19}$ Kolejną barierą dużo trudniejszą do przejścia są postawy parafian wobec osób niepełnosprawnych. Choć obecność osób niepełnosprawnych w przestrzeni publicznej niewątpliwie wzrasta, to nie przekłada się to na poprawę postaw społecznych wobec nich. ${ }^{20}$ Ciągle pokutują stereotypy, iż niepełnosprawność jest wynikiem grzechu, złego postepowania osoby niepełnosprawnej lub jej rodziców. Lęk, niepokój to częsta reakcja jaka towarzyszy w kontaktach z osobami niepełnosprawnymi, a nawet postrzeganie tych osób, jako tych, które mogą wnieść nieszczęście do rodziny otwierającej się na relacje z nimi.

Ważnym elementem wykluczającym pełne uczestnictwo osób niepełnosprawnych w zgromadzeniach wiernych są bariery w komunikacji (brak materiałów dostosowanych dla osób niewidomych i niedowidzących, niewystarczające nagłośnienie) oraz ograniczenia w dostępie do sakramentów ( I Komunia Święta, Bierzmowanie) dla osób niepełnosprawnych z głębokim upośledzeniem umysłowym. Toczy się dyskusja czy takie osoby powinny być dopuszczone do pozostałych sakramentów wtajemniczenia chrześcijańskiego czy też nie.

18 Franiszek, Przemówienie do chorych i niepetnosprawnych w Rzymie, http:// jedenznas.pl/papiez-franciszek-o-osobach-chorych-niepelnosprawnych/ (29.11.2016). 19 Zob. II Polski Synod Plenarny (1991-1999), Liturgia Kościoła po Soborze Watykańskim II, Poznań 2001, nr 139, s. 212.

20 Por. CBOS, Postawy wobec osób niepełnosprawnych. Komunikat z badań, Warszawa 207, BS/169/2007. http://www.cbos.pl/SPISKOM.POL/2007/K_169_07. PDF (07.04.2016). 
Podsumowując powyższe rozważania możemy dostrzec, że osoby niepełnosprawne w dalszy ciągu są wykluczone z życia społecznego a co z tym idzie nie mają możliwości realizacji swoich planów życiowych na poziomie osób pełnosprawnych. Istnieją obszary, w których następuje niewielka zmiana w stosunku do osób niepełnosprawnych, ale widzimy, że jest jeszcze wiele do zrobienia, również we wspólnocie Kościoła.

\section{Streszczenie}

Artykuł porusza tematykę wykluczenia społecznego dotyczącego wielu grup społecznych. Niepełnosprawni dotknięci wykluczeniem społecznym powinni mieć zapewnione wsparcie ze strony Kościoła oraz instytucji państwowych.

\section{Summary}

The article focuses on the theme of social exclusion for many social groups. Disabled affected by social exclusion should be provided with the support of the Church and state institutions.

Słowa kluczowe: wykluczenie społeczne, marginalizacja, niepełnosprani, Kościół.

Key words: social exclusion, marginalization, the disabled, the Church.

\section{Bibiografia}

Barnes C., Mercer G., Niepetnosprawnośćość, Warszawa 2008, s. 56-63.

CBOS, Postawy wobec osób niepełnosprawnych. Komunikat z badań, Warszawa 207, BS/169/2007, http://www.cbos.pl/SPISKOM. POL/2007/K_169_07.PDF (07.04.2016).

Franiszek, Przemówienie do chorych i niepetnosprawnych $w$ Rzymie, http:// jedenznas.pl/papiez-franciszek-o-osobach-chorych-niepelnosprawnych/ (29.11.2016).

II Polski Synod Plenarny (1991-1999), Liturgia Kościoła po Soborze Watykańskim II, Poznań 2001, nr 139.

J. Kirenko, Twórczość osób niepetnosprawnych, w: W. Janocha (red.), Niepełnosprawność. Wybrane aspekty sytuacji osób niepełnosprawnych i ich rodzin, red. W. Janocha, Kielce 2006.

Jan Paweł II, Encyklika. Sollicitudo rei socialis. 
Jan Paweł II, Przesłanie Jana Pawła II do uczestników międzynarodowego sympozjum na temat: Godność i prawa osoby z upośledzeniem umysłowym, nr 4, http://www.opoka.org.pl/biblioteka/W/WP/jan_pawel_ii/ przemowienia/uposledzenie_05012004.html (3.12.2016).

Janocha W., Marginalizacja i wykluczenie osób niepetnosprawnych z obszarów życia społecznego i religijnego, Roczniki Nauk o Rodzinie i pracy Socjalnej, 4(59) 2012.

Kilian M., Niepetnosprawni w społeczeństwie, Polityka Społeczna, 404- 405(11-12), 2007.

Kubicki D., Ubóstwo i wykluczenie społeczne osób starszych, Ekspertyza przygotowana w ramach projektu „EAPN Polska - razem na rzecz Europy Socjalnej", http://www.eapn.org.pl/ (03.12.2016).

Kwaśniewski J., Postrzeganie marginalizacji oraz strategii środków kontroli społecznej, w: J. Kwaśniewski (red.), Kontrola społeczna procesów marginalizacji, Warszawa 1997.

Marks-Bielska R., Marginalizacja społeczno-ekonomiczna wświetle polskiej literatury przedmiotu - lata 90., Polityka Społeczna nr 3 (2003).

Nogowski J., Wykluczenie społeczne w kontekście ubóstwa i bezdomności, Civitas et lex 2015/1(5).

Szarfenberg R., Pojęcie wykluczenia społecznego, http://rszarf.ips.uw.edu.pl/ pdf/pojecie_ws.pdf (11.12.2016).

Zespół Zadaniowy do Spraw Reintegracji Społecznej, www.mpips.gov.pl/ userfiles/File/mps/NSIS.pdf (07.04.2015).

\section{Biogram}

Błażej Szostek (ur. 1983), teolog pastoralista, psycholog o specjalności klinicznej, wykładowca akademicki, psychoterapeuta w trakcie certyfikacji w Ośrodku Intra. Studia specjalistyczne ukończył na Uniwersytecie Kardynała Stefana Wyszyńskiego, otrzymując tytuł magistra psychologii w 2009 roku oraz stopień doktora teologii w 2011 roku. Od 2011 roku zatrudniony na UKSW na stanowisku adiunkta w Katedrze Teologii Pastoralnej i nauk pomocniczych. Pracuje także w poradniach zdrowia psychicznego udzielając pomocy psychologicznej. Od 2012 roku doktorant w Instytucie Psychologii UKSW. Członek redakcji pisma naukowego Warszawskie Studia Pastoralne. Autor artykułów naukowych z dziedziny teologii i psychologii publikowanych w polskich i zagranicznych czasopismach. 